\title{
The Role Of Von Willenbrand Factors As The Early Detection Of Endotel Cell Damage In Youth Ages With Obesity In The USU Medan Campus Environment
}

\author{
Muhammad Syahputra $^{1 *}$, Sry Suryani ${ }^{1}$, Rusdiana ${ }^{1}$ \\ ${ }^{1}$ Department of Biochemistry, Faculty of Medicine, Universitas Sumatera Utara, Medan, \\ Indonesia \\ *Email:muhamad@usu.ac.id
}

\begin{abstract}
Endothelial cells are a single layer that lines the entire vascular system. Endothelial dysfunction can be triggered by several main things, namely physical stress, oxidative stress and irritant substances. Obesity triggers an inflammatory process and metabolic disorders that will lead to increased oxidative stress. Long-term oxidative stress will cause damage to cells and tissues and trigger degenerative diseases. Damage to endothelial cells is expected to be detected by examining Von Willenbrand levels so that it can prevent complications of vascular dis orders early. This research is descriptive with cross sectional design. Carried out from March to October 2018 on the USU Campus. The first examination was done to measure body weight and height to determine body mass index, then performed lipid profile and blood sugar levels (KGD) in the sample, then examined von Willenbrand factor levels carried out in the integrated laboratory of USU FK using the method ELISA in both the sample group and the control group. The research subjects were adolescents aged 17-25 years with BMI> $25 \mathrm{~kg} / \mathrm{m} 2$ Data analysis was carried out using the T-Test statistical program, comparing two groups. Of the 40 obese subjects found Von Wilenbrand level values The lowest factor was $1.78 \mathrm{IU} / \mathrm{ml}$ and the highest was $35.60 \mathrm{IU} / \mathrm{ml}$. Whereas in 40 non-obese subjects Von Wilenbrand grade values were the lowest factor of $2.01 \mathrm{IU} / \mathrm{ml}$ and the highest was $45.10 \mathrm{IU} / \mathrm{ml}$. This difference was not statistically significant $(\mathrm{p}=0.661)$. Conclusion: There was no significant difference between the levels of Von Wilenbrand Factors in obese subjects with non-obese subjects
\end{abstract}

Keyword: Obesity, endothelial cells, Von Wilenbrand Factors

\section{INTRODUCTION}

2. Obesity at this time has become a health problem and is associated with an increase in non-communicable diseases. The prevalence of obesity is increasing in both developed and developing countries(1). Obesity has become an epidemic by contributing 35\% to morbidity and $15-$ $20 \%$ to death. Obesity does not cause death directly, but causes serious health problems that can spur cardiovascular and metabolic disorders(2).World Health Organization (WHO) reports that in 2015 around 1.4 billion adults aged 20 years and over are overweight, with a prevalence of $10 \%$ in men and $14 \%$ in women(1)). This number has doubled compared to 1980 (5\% in men and $8 \%$ in women). The highest prevalence still occurs in developed countries, such as in America and Europe who experience overweight $62 \%$ and $26 \%$ obesity. In Southeast Asia, overweight rates reach $14 \%$ and 3\% obesity(1). Research conducted by the Asia Pacific Cohort Study Collaboration(3), shows an increase in overweight pandemics by $20 \%$ to $40 \%$ year on year.Obesity is not only found in adulthood, but also in children and adolescents. Obesity at the age of children and adolescents will increase the risk of obesity in adulthood. The prevalence of obesity in the world in children aged 611 years has increased from $7 \%$ to $19 \%$ and $5 \%$ to $17 \%$ at the age of $12-19$ years during the period from 1980-2004(4). Riskesdas data in 2010 showed that the prevalence of over nutrition in Indonesia in the group of children aged 6-12 years was $9.2 \%$, the age group $13-15$ years was $2.5 \%$ and the age group 16-18 years was $1.4 \%(5)$. In developing countries, the factors that influence the high prevalence of obesity are changes in lifestyle and diet. Diets, especially in large cities, shift from traditional diets to western diets (especially in the form of fast food), namely types of foods that 
contain high energy, high cholesterol, high sodium but low in fiber. This is supported by the availability of places to eat that provide fast food, ease of obtaining and low prices, which is why this fast food type is an option for consumption. Increasing sedentary lifestyle, such as watching television, playing computer can lead to a decrease in physical activity(4). This is also as explained by Hadi AR (2005), which states that consumption of foods high in calories and fat and sedentary lifesytes are closely related to the increase in the prevalence of obesity. Adolescence is one of the important and decisive periods of growth and development in the next period of development. In adolescence there was also a change in attitudes and behavior in choosing food and drinks, which were influenced by peers and the environment(6.7).

3. Endothelial vascular cells are located between the bloodstream and the blood vessel wall in regulation of blood function Endothelial cell function between ain maintains blood supply, hemostasis, and antithrombotic and inflammatory functions. Damage to endothelial cells results in disorders of hemostasis and micro and macro vascular complications, which in turn will increase the morbidity and mortality rates of DM patients(8.9).

Obesity triggers an inflammatory process and metabolic disorders that will lead to increased oxidative stress. Long-term oxidative stress will cause cell and tissue damage and trigger degenerative diseases $(10,11)$.

\section{METHODS}

This research is descriptive with cross sectional design. Carried out from March to October 2018 on the USU Campus. The first examination was done to measure body weight and height to determine body mass index, then performed lipid profile and blood sugar levels (KGD) in the sample, then examined von Willenbrand factor levels carried out in the integrated laboratory of USU FK using the method ELISA in both the sample group and the control group. The research subjects were adolescents aged 17-25 years with BMI> $25 \mathrm{~kg} / \mathrm{m} 2$ Data analysis was carried out using the T-Test statistical program, comparing two groups.

\section{RESULT AND DISCUSSION}

The characteristics of the obese and non-obese research subjects can be seen in Table 1

\begin{tabular}{ccc}
\hline Characteristic & Not Obese & Obese \\
\hline Male & $19(47.5 \%)$ & $17(42.5 \%)$ \\
Female & $21(52.5 \%)$ & $17(42.5 \%)$ \\
Age & $20(17-24)$ & $21(18-24)$ \\
Kamis & $05 / 12 / 2019$ & Dodo \\
\hline
\end{tabular}

Tabel 3.1. The characteristics of the obese and non-obese research

In Table 1, the number of male subjects who are not obese is 19 (47.5\%) while there are 21 (52.5\%) women. While the number of obese subjects was 17 (42.5\%) male and 23 female(57.5\%) people. For the age group, the study subjects who were not obese had an age range of 17-24 years. Meanwhile, obese research subjects have an age range of 18-24 years. VWF levels in obese and nonobese subjects can be seen Table 2

\section{CONCLUSION}

\begin{tabular}{cccc}
\hline Group & $\mathrm{N}$ & $\begin{array}{c}\text { Average grade } \\
\text { VWF (IU/ml) }\end{array}$ & $\mathrm{p}$ Value \\
\hline Obese & 40 & $35(1.78-35.60)$ & $\mathrm{P}=0.661$
\end{tabular}


Rusdiana et al . The Role Of Von Willenbrand Factors As The Early

Not Obese $\quad 40 \quad\lfloor 5(2.01-45.10)$

Table 3.2. Analysis of VWF levels

In Table 2, the lowest value range of VWF levels in obese subjects is $1.78 \mathrm{IU} / \mathrm{ml}$ and the highest is $35.60 \mathrm{IU} / \mathrm{ml}$. Meanwhile, the lowest was $2.01 \mathrm{IU} / \mathrm{ml}$ and the highest was $45.10 \mathrm{IU} / \mathrm{ml}$. This difference was not statistically significant $(\mathrm{p}=0.661)$

\section{ACKNOWLEDGMENTS}

The authours gratefully acknowledge financially supported of the Ministry of Research and Technology and Higher Education Republic of Indonesia. The study was supported by the research grant TALENTA USU 2018.

\section{REFERENCES}

Asia Pacific Cohort Studies Collaboration, 2007. The burden of overweight and obesity in the Asia-Pacific region. Obes Rev. 2007 May;8(3):191-6. doi: 10.1111/j.1467789X.2006.00292.x. PMID: 17444961.

Cooper GM, Hansma RE.2003.The Cell a molecular approach, Washington; ASM Press. Lebowitz J. 2012. The effect of obesity and overweigth on health. California; Parmacist

K Kusoy. 2013. The prevalence of obesity in adolescents in Minahasa District . Journal ebiomedic.Unsrat.

Ministry of Health of the Republic of Indonesia. 2013. Basic health research, riskesdas. Jakarta.

Hadi AR,Carr Cs, Al Suwaidi J 2005. Endothelial dysfunction : cardiovascular risk factors, therapy and outcome. Vasc Helath and Risk Management; 1 (3): 183-98

Yamagishi, S., Nakamura, K., Mutsui, K., Noda, Y., dan Imaizumi, T. 2008.

RAGE: A Novel Therapeutic Target For Diabetic Vascular Complication.

Curr. Pharm. 14(5): 487-95.

Hollestelle MJ, et al..2011.Decreased active von Willenbrand factor level owing to shear stress in aortic stenosis patients. J Thromb Haemost.

Isnaini, Sartono A, Winaryati E. 2012. The relationship between knowledge of obesity and waist-to-hip ratio in housewives in Pepe Krajan village, Tegowono district, Grobogan district. J Journal of nutrition.UMS;1(1):1-8

Whiting, D. R., Guariguata, L., Weil, C., Shaw, J. 2011. IDF diabetes atlas: Global estimates of the prevalence of diabetes for 2011 and 2030. Diabetes research and clinical practice, 94, 311-321.

World Health Organization , 2015.Media Centre: Obesity and Overweight. Available from: http//www.who.int/mediacentre/factsheets/fs311/en/ (Acceed 20 April 2015). 